\title{
Dimensions of Destruction of Road Network Providing Access to Cadastral Parcels Resulting from Motorway Construction
}

\begin{abstract}
Issues specified in the study concern the evaluation of road networks providing access to cadastral parcels in villages divided by a motorway. The scope of the research involves a spatial analysis of three villages: Rogoźnica, Rudna Mała, and Lipie, all located in the Głogów Małopolski commune, in the county of Rzeszów. Based on data from the descriptive and cartographic part of the Land and Buildings register, a detailed analysis was made of the spatial structure and road network providing direct access to cadastral parcels. The conducted research has revealed that the motorway as a linear investment has not only caused the destruction of agricultural roads in the existing agricultural area but has also destroyed connections between villages that have been shaped for centuries.
\end{abstract}

Keywords: motorway, road network, spatial structure, comprehensive work of land consolidation and exchange

* Rzeszów School of Engineering and Economics, Department of Cadastre and Geodetic Spatial Planning, Rzeszów, Poland 


\section{Introduction}

The communication system is one of the key elements in the development of a commune spatial arrangement. Its effective functioning has a huge impact on accelerating development in the region. The aim of this system is to enable the efficient and economical transport of people and goods. Such a system enhances the attractiveness of a region by attracting entrepreneurs and satisfying the socio-economic needs of its citizens.

Man, as a human being, has transformed the natural landscape for his own needs without taking into account the negative effects. Agricultural land has been exposed to continuous divisions resulting from land inheritance or transfer. The listed elements have badly affected many village areas. There has been an increase in the number of plots, fragmentation, and changes in the land formation. Significant problems, however, have turned out to be poor technical condition and a total lack of roads providing access to parcels [8].

Access to agricultural plots is provided by roads that play an important role in agriculture. Frequently, extended plots are located in different areas where there is no access to them. A significant factor is the impact of constructing a motorway passing through a village. A motorway is an important part of social, economic, and cultural life, and it impacts interpersonal relationships as well. However, it crosses passes from cadastral parcels to habitats. It affects access to habitats and, thus, the functioning of the inhabitants. The linear route of the motorway includes hundreds of kilometers. It crosses cadastral parcels of many owners and badly affects the natural environment and its management [3]. Motorways that cross agricultural land affects the management and investment in agricultural production areas adjacent to the road lane, which results in a decreased value of the affected farms [2].

One of the negative results of this impact on farms is the deterioration of farmstead expanses, where the area of land decreases while the time of getting from the habitat to the cropland increases [14].

The most troublesome for agricultural production is cutting off and leaving small fragments of parcels on the opposite side of the habitat. It makes access to cadastral parcels of a given host complicated, prolonged, or sometimes even impossible [11]. Carrying out the project of land consolidation and exchange, we can observe that the road network is poorly developed in many villages of southeastern Poland. The problem is even more exacerbated since regulating the legal status of the roads is not an easy task [4]. What is more, there is a lack of synchronization between the data recorded in the Land and Buildings register and the factual state [1,9]. Among other things to analyze in the network of roads providing access to cadastral parcels according to the factual state, QGIS software was used for illustrating the phenomenon and improving the performance of the following analyses. 


\section{Characteristics of Research Object}

Lipie, Rogoźnica, and Rudna Mała are picturesque villages located in the southern part of the Głogów Małopolski commune. This commune is situated in the northern part of the county of Rzeszów, and it borders the city of Rzeszów at the south. The area of the examined villages is crossed by the A4 motorway, as shown graphically in Figure 1. The Głogów Małopolski commune occupies an area of $144.7 \mathrm{~km}^{2}$ and has 19,467 inhabitants. The population density is 135 people $/ \mathrm{km}^{2}$. It is the second most-populous commune in the county of Rzeszów.

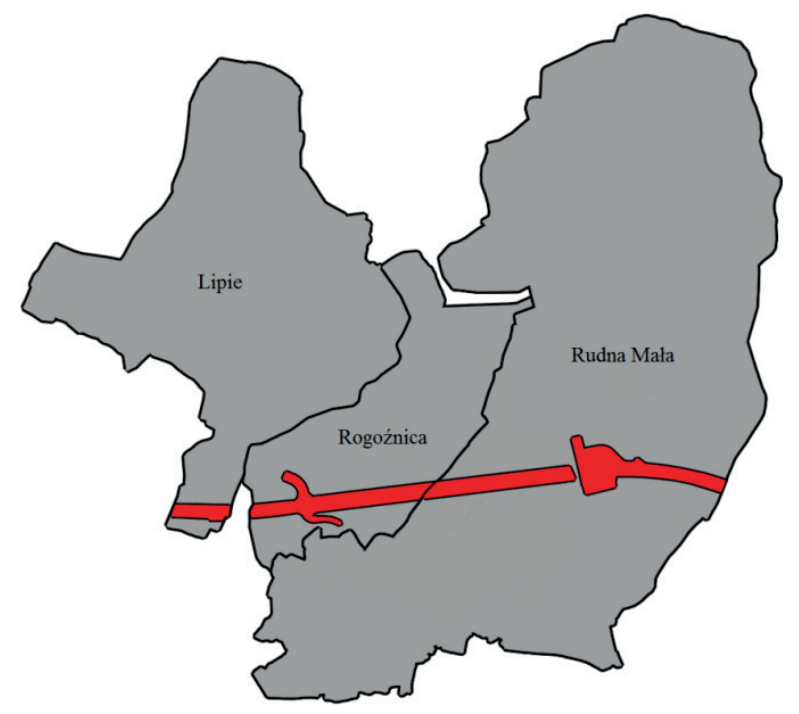

Fig. 1. A4 motorway route through villages of Lipie, Rogoźnica, and Rudna Mała

Source: own study on the basis of the Land and Buildings register

On the basis of Table 1, it can be concluded that the A4 motorway divides areas of the Lipie, Rogoźnica, and Rudna Mała villages into two parts: northern and southern. The route of the motorway in Lipie does not cause any significant destruction of the local roads, but it affects road connections between the villages situated outside the motorway. In Rogoźnica and Rudna Mała, the motorway breaks connections between villages and destructs the spatial arrangements of the villages and farms. The route of the motorway from Rzeszów Wschód (west junction) to Rzeszów Centralny (central junction) passes through the whole examined area. This section has a length of $4 \mathrm{~km}$ and was created in the areas of Świlcza and Głogów Małopolski. This investment constitutes the ring-road of Rzeszów. In the analyzed area, the motorway crosses two municipal roads: Mrowla to Lipie and Rudna Mała to Rogoźnica. In this area, there is one bridge built over a watercourse and a municipal road between Rudna Mała and Rogoźnica and one passage for small animals in Rudna Mała. 
Table 1. Analyzed villages crossed by motorway

\begin{tabular}{|c|c|c|c|c|c|c|c|c|c|}
\hline \multirow{3}{*}{ No. } & \multirow{3}{*}{$\begin{array}{l}\text { Cadastral unit } \\
\text { name }\end{array}$} & \multirow{2}{*}{\multicolumn{2}{|c|}{ Total area }} & \multicolumn{4}{|c|}{$\begin{array}{l}\text { Village area created as a result of the division } \\
\text { caused by the motorway }\end{array}$} & \multirow{2}{*}{\multicolumn{2}{|c|}{$\begin{array}{c}\text { Area } \\
\text { occupied for } \\
\text { the motorway }\end{array}$}} \\
\hline & & & & \multicolumn{2}{|c|}{$\begin{array}{l}\text { Area cut off in the } \\
\text { northern direction } \\
\text { along the motorway }\end{array}$} & \multicolumn{2}{|c|}{$\begin{array}{l}\text { Area cut off in the } \\
\text { southern direction } \\
\text { along the motorway }\end{array}$} & & \\
\hline & & ha & $\%$ & ha & $\%$ & ha & $\%$ & ha & $\%$ \\
\hline 1 & Lipie & 534 & 26.5 & 524 & 98.1 & 5 & 0.9 & 5 & 0.9 \\
\hline 2 & Rogoźnica & 259 & 12.9 & 192 & 74.1 & 47 & 18.1 & 20 & 7.7 \\
\hline 3 & Rudna Mała & 1,221 & 60.6 & 774 & 63.4 & 414 & 33.9 & 33 & 2.7 \\
\hline & Total: & 2,014 & 100.0 & 1,490 & 74.0 & 466 & 23.1 & 58 & 2.9 \\
\hline
\end{tabular}

Source: own study on the basis of [2]

Another important route in the examined area is the national road running through Głogów Małopolski and linking Radom with Barwinek. The section running through the examined commune has a length of $14.2 \mathrm{~km}$. Apart from the aforementioned routes, there are also county roads with a total length of $72.65 \mathrm{~km}$ and municipal roads with a total length of $65.23 \mathrm{~km}$. Among the roads administered by the commune, unpaved roads account for as much as $21.32 \mathrm{~km}$. This adds up to $32.68 \%$ of all municipal roads in the region.

Table 2. Study on fragmentation

\begin{tabular}{|c|c|c|c|c|c|c|c|c|c|c|}
\hline \multirow[t]{2}{*}{ No. } & \multirow[t]{2}{*}{$\begin{array}{l}\text { Cadastral } \\
\text { unit name }\end{array}$} & \multicolumn{2}{|c|}{ Total area } & \multicolumn{2}{|c|}{$\begin{array}{l}\text { Total area } \\
\text { in the } \\
\text { individual } \\
\text { grounds }\end{array}$} & \multirow{2}{*}{$\begin{array}{c}\text { Total } \\
\text { number } \\
\text { of plots } \\
\text { in the } \\
\text { cadastral } \\
\text { unit }\end{array}$} & \multirow{2}{*}{$\begin{array}{l}\text { Total } \\
\text { number of } \\
\text { plots in the } \\
\text { individual } \\
\text { grounds }\end{array}$} & \multirow{2}{*}{$\begin{array}{c}\text { Average } \\
\text { plot area } \\
\text { in the } \\
\text { cadastral } \\
\text { unit } \\
\text { ha }\end{array}$} & \multirow{2}{*}{$\begin{array}{l}\text { Average } \\
\text { plot area } \\
\text { in the } \\
\text { individual } \\
\text { grounds } \\
\text { ha }\end{array}$} & \multirow{2}{*}{$\begin{array}{l}\text { Number } \\
\text { of owners } \\
\text { in the in- } \\
\text { dividual } \\
\text { grounds }\end{array}$} \\
\hline & & ha & $\%$ & ha & $\%$ & & & & & \\
\hline 1 & Lipie & 534 & 26.5 & 375 & 70.2 & 1,722 & 1,478 & 0.31 & 0.25 & 650 \\
\hline 2 & Rogoźnica & 259 & 12.9 & 169 & 65.3 & 1,469 & 1,050 & 0.18 & 0.16 & 602 \\
\hline 3 & $\begin{array}{l}\text { Rudna } \\
\text { Mała }\end{array}$ & 1,221 & 60.6 & 451 & 36.9 & 3,809 & 2,793 & 0.32 & 0.16 & 2,493 \\
\hline & Total: & 2,014 & 100 & 995 & 49.4 & 7,000 & 5,321 & 0.29 & 0.19 & 3,745 \\
\hline
\end{tabular}

Rudna Mała, Lipie, and Rogoźnica together occupy an area of 2,014 ha. Their spatial structures are presented in Table 2 and Figure 2. The largest area is occupied by individual grounds. Their percentage share in the area of the whole discussed region is 995 ha, which accounts for $49.4 \%$ of the total area. Another large group is the land of the State Treasury; its total area is 641 ha $(31.8 \%)$. Such a large share of this group of properties in the total area of the region results primarily from the presence of the state-owned forests in this region. In addition, the investment in the A4 motorway transferred ownership of the area of its location to the State Treasury (as can be seen in Figure 2). 


\section{Legend}

State Treasury

Land of the State Treasury put into perpetual usufruct

One-man state-owned companies

Communes and inter-municipal unions

Communes and inter-municipal unions with perpetual users

Owners in the individual grounds

Cooperatives

Counties and unions of counties

Province

Commercial law company

Churches and religious associations

- Border village
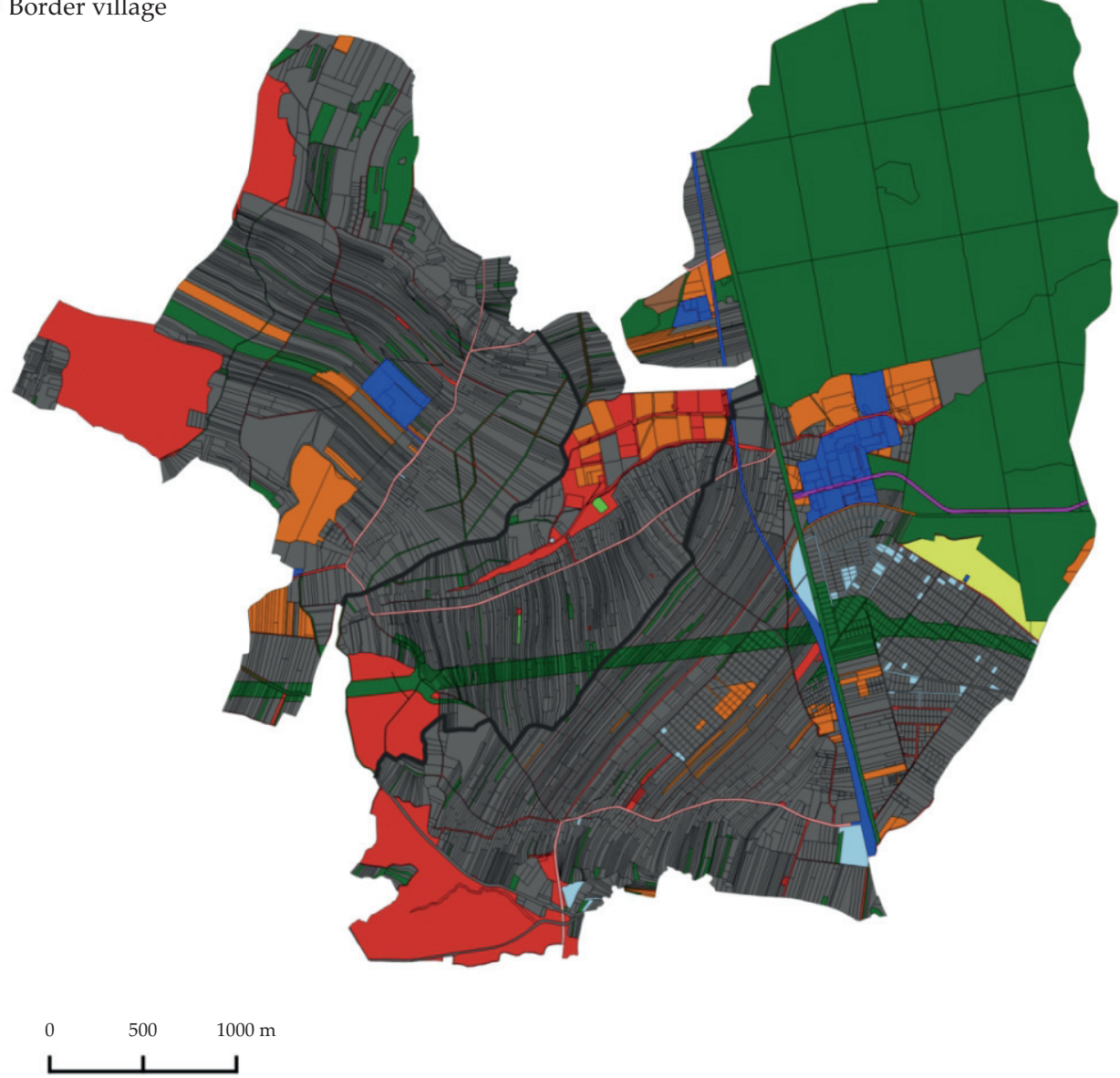

Fig. 2. Spatial structure of Lipie, Rogoźnica, and Rudna Mała

In southern and southeastern Poland, a strip-type plot patchwork prevails; this is also the case in the analyzed villages. This strip type occurs in Lipie and Rogoźnica, and a strip-ladder subtype occurs in Rudna Mała, with a parallel arrangement of roads in Rogoźnica and Rudna Mała and a combined arrangement in Lipie [12]. 
Such an arrangement of plots causes very large land fragmentation. In the analyzed cadastral units, the average plot area is 0.29 ha. This result is below the average plot area of 0.42 ha on the scale of Podkarpackie Voivodship [10]. Among other things, the result of such a low average is that such a motorway route through the examined village very often causes the necessity of setting out two or three new plots from one cadastral parcel.

\section{Dimensions of Destruction of Road Network Providing Access to Cadastral Parcels}

\subsection{Definition of Road}

In terms of the Act on Public Roads [13], a road is a structure together with its equipment, engineering facilities, and installations that, as a technical and functional unit, is intended for road communication and located in the road lane.

A public road [13] is a road classified on the basis of the Act on Public Roads to one of the categories of roads accessible to anyone in accordance to its purpose, with limitations and exceptions specified in this act or in other specific regulations.

Due to their functions, public roads can be divided into national roads, provincial roads, county roads, and municipal roads. National roads are owned by the State Treasury. In particular, they include motorways, express roads, international roads, ring roads around large agglomerations, and roads of defensive importance. Provincial roads are roads of great importance for the voivodship. They are roads that connect cities, but they also hold defensive importance (along with national roads). Roads linking county seats with commune villages and commune seats among themselves are classified as county roads. Municipal roads are roads of local importance and are not included in other categories, constituting a complementary road network serving local needs. However, municipal roads do not include private roads.

In the examined area, the network of road infrastructure is composed of unpaved roads in most cases and are very often impassable for modern agricultural machinery. This network is sometimes too rare and it does not provide adequate access to all fields (or can be too dense in the case of large land fragmentation). In turn, this facilitates access to the land but at the same time involves losses of agricultural land and aggravates the possibility of setting out fields with rational areas and shapes [6]. Therefore, the features of this network significantly influence the possibilities of optimizing the use of agricultural land.

\subsection{Analysis of Road Network Providing Access to Cadastral Parcels in Lipie}

Based on the data from the descriptive and cartographic part of the Land and Buildings register, an analysis of the network of existing roads and access to parcels 
was made. In the research, analytical, descriptive, and cartographic methods were used to demonstrate the distribution of cadastral parcels without access on the maps of the Land and Buildings register presenting particular villages.

1,606 out of all 1,722 parcels were taken into account in the analysis of the road network in Lipie. The selected parcels occupy a total area of 510.63 ha. They were analyzed in terms of road accessibility and divided into parcels without access to a road, parcels with access to a road, and those accessible via a road located in a neighboring village. Parcels that were roads and those set out as ditches were excluded from the examination. There were 116 such parcels with a total area of 21 ha.

In Lipie, the road of national importance is the A4 motorway. It passes through the southern part of the village, dividing it into two parts: north and south. The division is unequal, since the northern part is definitely bigger. The area of the southern part accounts for only $0.9 \%$ of the total area.

The road network is situated mainly north of the motorway. The southern part is practically devoid of it. However, due to the collective roads that run parallel to the motorway and one road in this area, most of the plots located there are accessible. Nevertheless, communication of the opposite part of Lipie has deteriorated. There is no single pass from one side of the motorway to the other over or under the full portion of the A4 motorway situated in Lipie.

The obtained results are presented in Table 3 and Figure 3, where detailed results of the access of plots to particular roads are also demonstrated.

Table 3. Accessibility of plots to roads in Lipie

\begin{tabular}{|c|c|c|c|c|c|c|}
\hline \multirow{2}{*}{ No. } & \multirow{2}{*}{$\begin{array}{l}\text { Cadastral unit } \\
\text { name }\end{array}$} & \multirow{2}{*}{ Cadastral parcels } & \multicolumn{2}{|c|}{$\begin{array}{l}\text { Number of } \\
\text { parcels }\end{array}$} & \multicolumn{2}{|c|}{ Area } \\
\hline & & & quantity & $\%$ & ha & $\%$ \\
\hline 1 & \multirow{7}{*}{ Lipie } & $\begin{array}{l}\text { Parcels with access to the road recorded } \\
\text { in the Land and Building register (EGiB) }\end{array}$ & 1,027 & 59.6 & 353 & 66.1 \\
\hline 2 & & $\begin{array}{l}\text { Parcels with access to the road located in } \\
\text { a neighboring village (NV) }\end{array}$ & 14 & 0.8 & 3 & 0.6 \\
\hline 4 & & All parcels with access to roads & 1,041 & 60.5 & 356 & 66.7 \\
\hline 5 & & Parcels without access to roads & 565 & 32.8 & 157 & 29.4 \\
\hline 6 & & Roads & 94 & 5.5 & 13 & 2.4 \\
\hline 7 & & Ditches and waters & 22 & 1.3 & 8 & 1.5 \\
\hline 8 & & Total: & 1,722 & 100.0 & 534 & 100.0 \\
\hline
\end{tabular}

In Lipie, 94 cadastral parcels constitute roads, of which as many as 37 parcels comprise the A4 motorway. The remaining 57 parcels create a network that serves for local use. The biggest number of plots are accessed by the road designated by parcel no. 1131. It provides access to 209 other parcels, which accounts for $13.01 \%$ 
of all analyzed parcels. This road crosses Lipie from southwest to northeast; it is a county road. A number of municipal roads lead from that county road and are complementary to the network of roads in order to provide the best communication in the village. Another significant road is a county road comprising parcel no. 1049. Thanks to it, 69 parcels have access to the road. Parcels 50/2 and 789/1 are also important (providing access to parcels that represent $12.28 \%$ and $3.13 \%$ of the area, respectively). These parcels are parts of municipal roads.

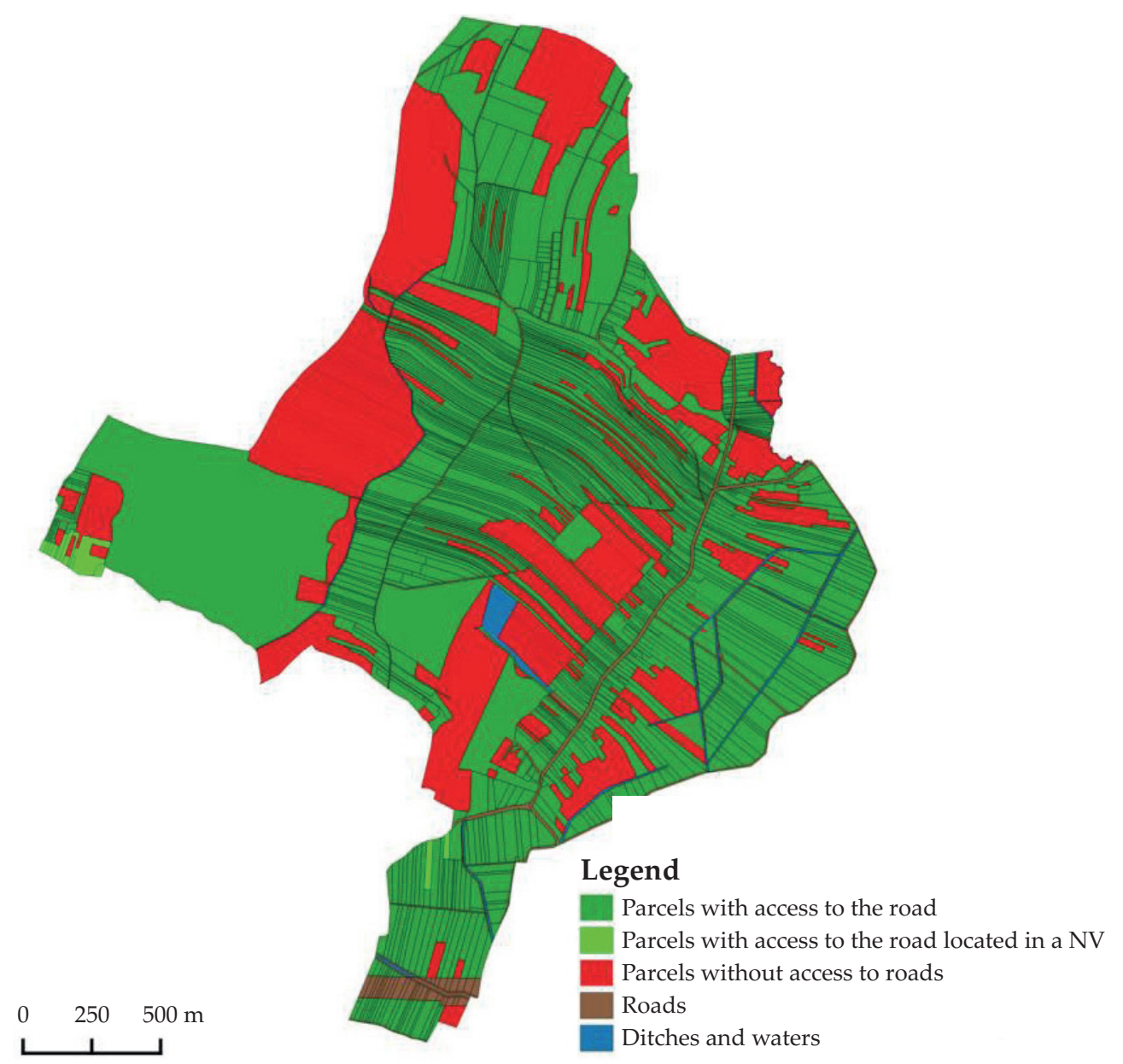

Fig. 3. Accessibility of plots to roads in Lipie

Other roads individually do not provide communication to a large number of parcels but are complementary to the main network components. The road network in Lipie is additionally supported by roads adjacent to the area. Fourteen cadastral parcels of the analyzed area are served by two roads located outside its borders. 
Table 3 shows that as many as $32.8 \%$ of the parcels do not have access to the road. Figure 3 presents the largest concentrations of these parcels. These are located in the southeastern and central parts of the village. They are accessible, which was verified using Web Map Service (WMS) from the geoportal.gov.pl website. Though there is an area used as an access road to these parcels, it was not properly set out. Making this area accessible is a matter of agreement between parcel owners. Another reason for such a large number of parcels without access to the road is using formed gravel pits to create a complex of ponds. They are located in the central part of Lipie. Ponds cover an area of about 10 ha and consist of many cadastral parcels; as single plots, these have direct access to the road only to a small extent.

The next stage of the analysis was to verify the obtained results. After consulting the data from Web Map Service (WMS) as well as an on-site verification, the previously identified roads were verified. Finally, parcels not recorded in the Land and Buildings register (EGiB) as public roads were also excluded; however, they are in fact parcels clearly indicating that they serve as access roads to plots located away from the roads recorded in the EGiB database. As a result of this analysis, Table 4 and Figure 4 were created. Twenty-four parcels were identified, providing 73 additional plots with access to the road. Their area is 37 ha. In summary, it can be concluded that $32.8 \%$ of the parcels did not have access to the road in the examined area. However, after verification of the parcels, the situation improved by $5 \%$.

Table 4. Accessibility of plots to roads in Lipie after verification

\begin{tabular}{|c|c|c|c|c|c|c|}
\hline \multirow{2}{*}{ No. } & \multirow{2}{*}{$\begin{array}{l}\text { Cadastral unit } \\
\text { name }\end{array}$} & \multirow{2}{*}{ Cadastral parcels } & \multicolumn{2}{|c|}{$\begin{array}{l}\text { Number of } \\
\text { parcels }\end{array}$} & \multicolumn{2}{|c|}{ Area } \\
\hline & & & quantity & $\%$ & ha & $\%$ \\
\hline 1 & \multirow{9}{*}{ Lipie } & $\begin{array}{l}\text { Parcels with access to the road recorded } \\
\text { in the Land and Building register } \\
\text { (EGiB) }\end{array}$ & 1,007 & 58.5 & 353 & 66.1 \\
\hline 2 & & $\begin{array}{l}\text { Parcels with access to the road located } \\
\text { in a neighboring village (NV) }\end{array}$ & 14 & 0.8 & 3 & 0.6 \\
\hline 3 & & $\begin{array}{l}\text { Parcels with access to parcels classified } \\
\text { as roads }\end{array}$ & 73 & 4.2 & 37 & 6.9 \\
\hline 4 & & All parcels with access to roads & 1,094 & 63.5 & 393 & 73.6 \\
\hline 5 & & Parcels without access to roads & 488 & 28.3 & 117 & 21.9 \\
\hline 6 & & Roads & 94 & 5.5 & 13 & 2.4 \\
\hline 7 & & Parcels classified as roads & 24 & 1.4 & 3 & 0.6 \\
\hline 8 & & Ditches and waters & 22 & 1.3 & 8 & 1.5 \\
\hline 9 & & Total: & 1,722 & 100.0 & 534 & 100.0 \\
\hline
\end{tabular}




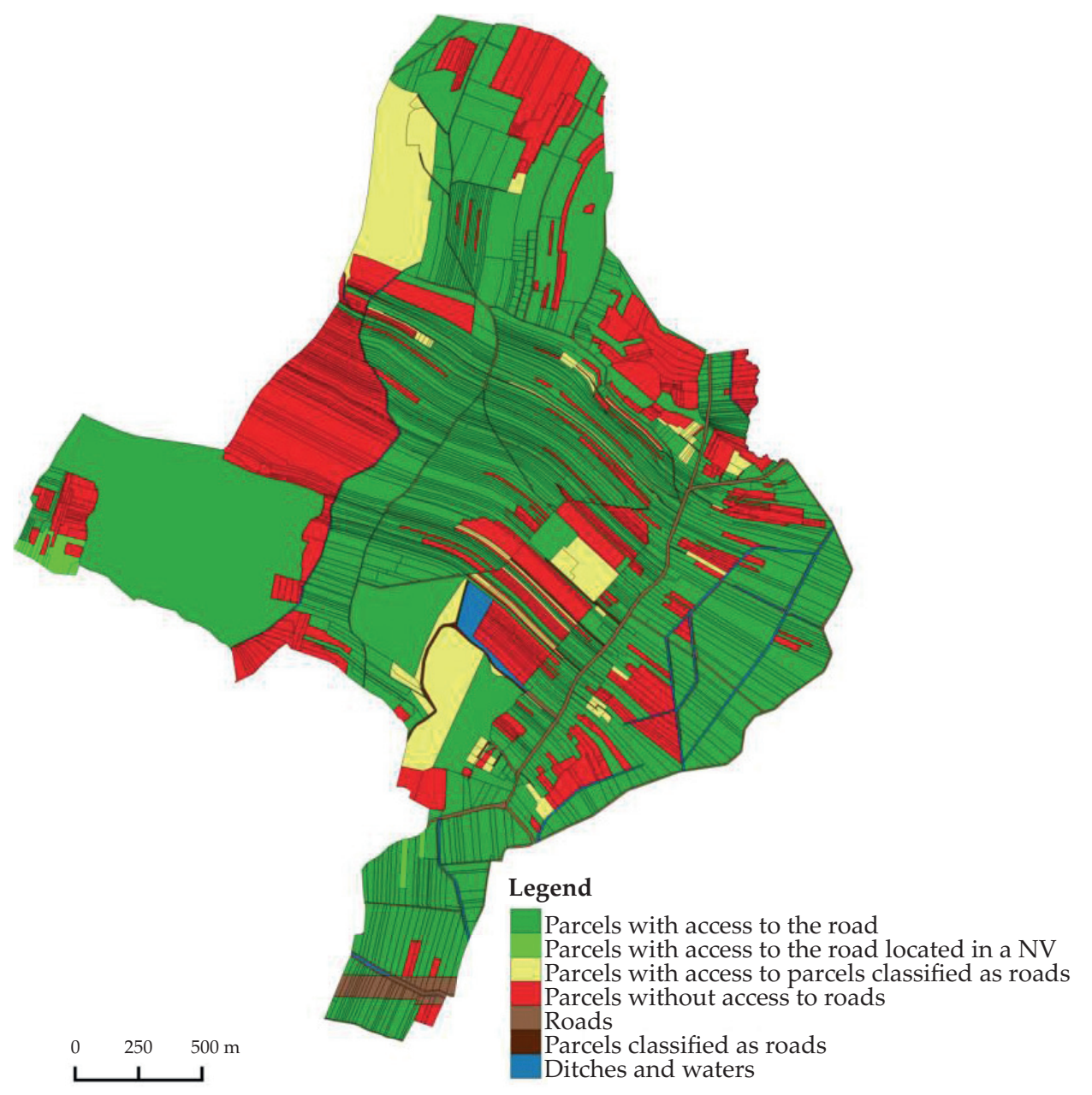

Fig. 4. Accessibility of plots to roads in Lipie after verification

\subsection{Analysis of Road Network Providing Access to Cadastral Parcels in Rogoźnica}

1,161 parcels with an area of 228 ha were accepted for the analysis in Rogoźnica. The remaining parcels not included in the examination are roads and ditches; there are 308 of these, and their common area is 31 ha. The road network in Rogoźnica consists of 281 parcels, of which 217 parcels form a part of the motorway. The motorway passes through the southern part of the village and divides it into two parts, of which the northern part covers a definitively larger area. The service roads created during motorway construction are an important part of the local communication. They provide access to 169 parcels (14.54\% of the total number). However, the problem is with passing from one side of the motorway to the other. This mainly 
concerns those farms whose cadastral parcels are divided in such a way that they are located on both sides of the motorway. In this village, we can talk about 72 farms divided by the motorway lane. This is a significant number, bearing in mind that there are only 445 farms in Rogoźnica. Such a layout of farms not only increases working time but also the costs associated with operating the equipment necessary for serving farms. The results indicate that lengthening an access road from the habitat to the parcel results in an estimated loss of 5-10\% [7]. It would be most optimal if this distance did not exceed $0.5-1.0 \mathrm{~km}$. In the case of an unfavorable farm layout, a good solution is to exchange plots as a part of tasks connected with land consolidation and exchange [5].

The main artery of the village serving the plots is a county road running from west to east. Most municipal roads lead from this county road. This road is represented as one parcel and provides access to the road for 280 plots with a total area of 57.95 ha. Like in Lipie, other roads do not have a single significant role in creating a road network; but altogether, they form a network of parallel roads. The results of this analysis are presented in Table 5 and Figure 5.

Table 5. Accessibility of plots to roads in Rogoźnica

\begin{tabular}{|c|c|c|c|c|c|c|}
\hline \multirow{2}{*}{ No. } & \multirow{2}{*}{$\begin{array}{l}\text { Cadastral unit } \\
\text { name }\end{array}$} & \multirow{2}{*}{ Cadastral parcels } & \multicolumn{2}{|c|}{$\begin{array}{c}\text { Number of } \\
\text { parcels }\end{array}$} & \multicolumn{2}{|c|}{ Area } \\
\hline & & & quantity & $\%$ & ha & $\%$ \\
\hline 1 & \multirow{7}{*}{ Rogoźnica } & $\begin{array}{l}\text { Parcels with access to the road recorded } \\
\text { in the Land and Building register (EGiB) }\end{array}$ & 894 & 60.9 & 186 & 71.8 \\
\hline 2 & & $\begin{array}{l}\text { Parcels with access to the road located in } \\
\text { a neighboring village (NV) }\end{array}$ & 15 & 1.0 & 5 & 1.9 \\
\hline 4 & & All parcels with access to roads & 909 & 61.9 & 191 & 73.7 \\
\hline 5 & & Parcels without access to roads & 252 & 17.2 & 37 & 14.3 \\
\hline 6 & & Roads & 281 & 19.1 & 26 & 10.0 \\
\hline 7 & & Ditches and waters & 27 & 1.8 & 5 & 1.9 \\
\hline 8 & & Total: & 1,469 & 100.0 & 259 & 100.0 \\
\hline
\end{tabular}

As shown in Table 5 and Figure 5, only 17.2\% of the parcels do not have access to the road, while $61.9 \%$ of cadastral parcels have access to roads located in the examined area. The strip-type layout of the parcels shows that access to roads exist in practice, but such an arrangement of parcels is not suitable for land management. On the other hand, parcels without access to the road in Rogoźnica have often resulted from the division of plots (which were divided at right angles to the longer side due to their oblong shape). The reason for this was the desire to avoid creating very narrow parcels. The remaining 1\% (i.e., 15 parcels) have access to roads located in a neighboring village. 
After analysis of the received data, the obtained results were verified. Table 6 and Figure 6 present the results of these verifications. They revealed that, in fact, only $12.3 \%$ of the Rogoźnica area does not have access to the road. In this case, this single factor is not enough for the use of cadastral parcels located there.

Table 6. Accessibility of plots to roads in Rogoźnica after verification

\begin{tabular}{|c|c|c|c|c|c|c|}
\hline \multirow{2}{*}{ No. } & \multirow{2}{*}{$\begin{array}{l}\text { Cadastral unit } \\
\text { name }\end{array}$} & \multirow{2}{*}{ Cadastral parcels } & \multicolumn{2}{|c|}{$\begin{array}{l}\text { Number of } \\
\text { parcels }\end{array}$} & \multicolumn{2}{|c|}{ Area } \\
\hline & & & quantity & $\%$ & ha & $\%$ \\
\hline 1 & \multirow{9}{*}{ Rogoźnica } & $\begin{array}{l}\text { Parcels with access to the road recorded } \\
\text { in the Land and Building Register (EGiB) }\end{array}$ & 868 & 59.1 & 183 & 70.7 \\
\hline 2 & & $\begin{array}{l}\text { Parcels with access to the road located in } \\
\text { a neighboring village (NV) }\end{array}$ & 15 & 1.0 & 5 & 1.9 \\
\hline 3 & & $\begin{array}{l}\text { Parcels with access to parcels classified } \\
\text { as roads }\end{array}$ & 73 & 5.0 & 13 & 5.0 \\
\hline 4 & & All parcels with access to roads & 956 & 65.1 & 201 & 77.6 \\
\hline 5 & & Parcels without access to roads & 180 & 12.3 & 24 & 9.3 \\
\hline 6 & & Roads & 281 & 19.1 & 26 & 10.0 \\
\hline 7 & & Parcels classified as roads & 25 & 1.7 & 3 & 1.2 \\
\hline 8 & & Ditches and waters & 27 & 1.8 & 5 & 1.9 \\
\hline 9 & & Total: & 1,469 & 100.0 & 259 & 100.0 \\
\hline
\end{tabular}

\subsection{Analysis of Road Network Providing Access to Cadastral Parcels in Rudna Mała}

In the cadastral unit of Rudna Mała, access of the parcels to roads was analyzed in an area of 1,128 ha comprised of 3,336 cadastral parcels. Out of the 3,809 parcels belonging to this unit, 473 parcels were set out, including those that are parts of roads, ditches, and communication areas. The A4 motorway consists of 333 cadastral parcels. It passes through the southern part of the village, dividing it into two parts: northern $(63.4 \%)$ and southern. In this unit, there is a junction linking National Road no. 9 with National Road no. 19. This is the only passover from one side of the motorway to the other in this unit. On both sides of the motorway, there are mainly collective roads providing access to roads for the cadastral parcels adjacent to the motorway. Another road of national importance in Rudna Mała is National Road no. 9, leading from Rzeszów to Radom. There is also a provincial road linking National Roads no. 9 and no. 19 with the airport in Jasionka. 


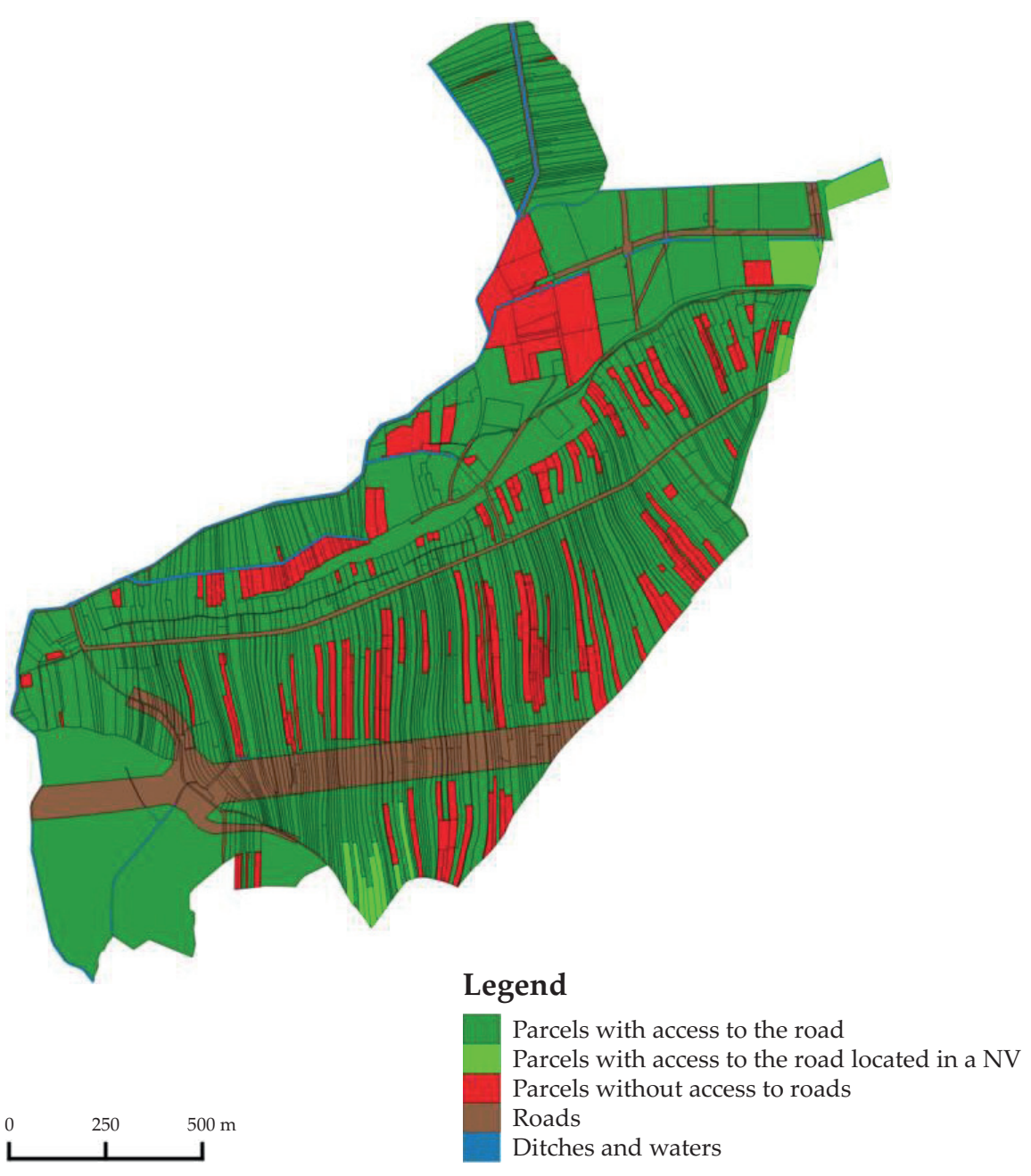

Fig. 5. Accessibility of plots to roads in Rogoźnica

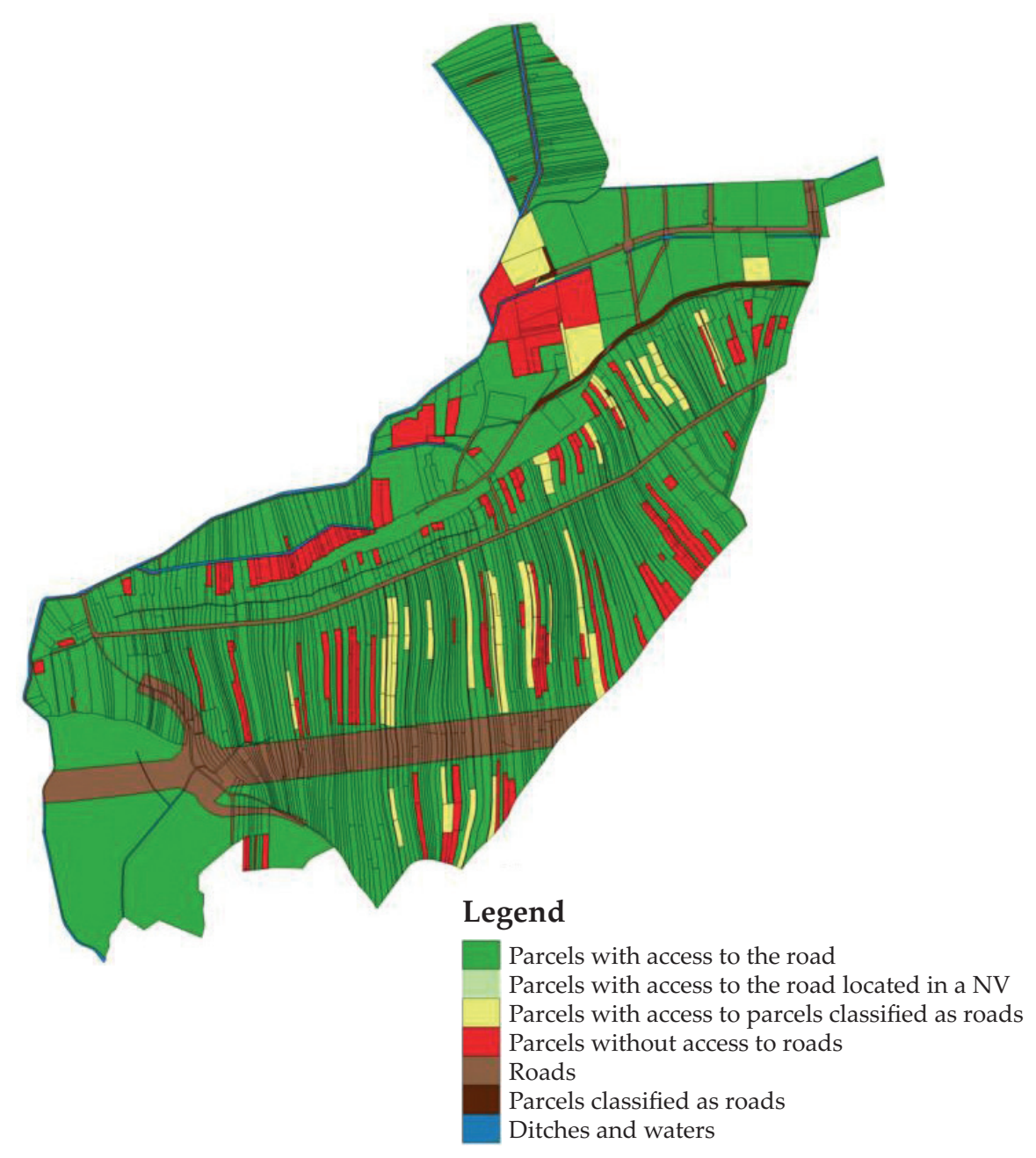

Fig. 6. Accessibility of plots to roads in Rogoźnica after verification 

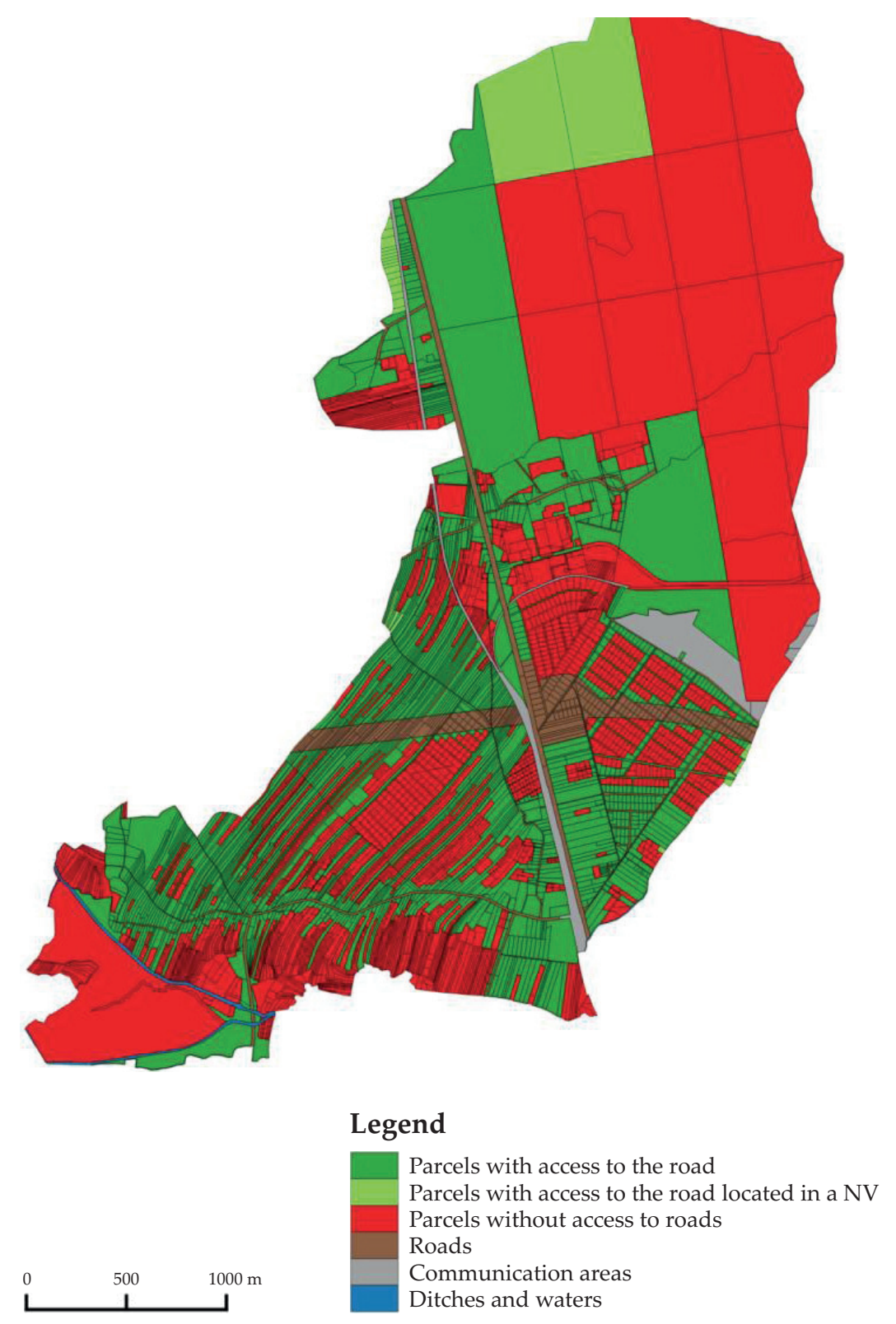

Fig. 7. Accessibility of plots to roads in Rudna Mała

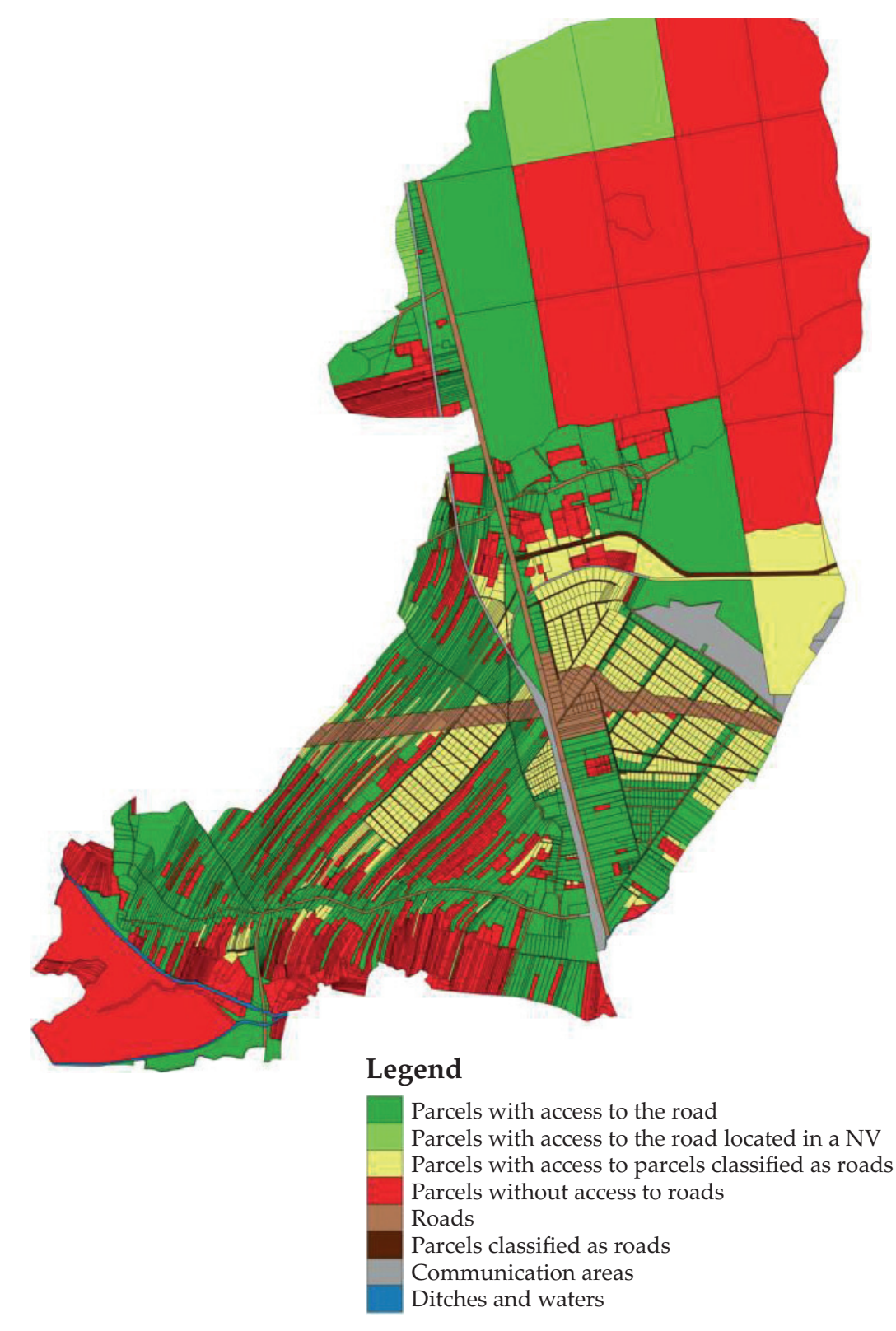

Fig. 8. Accessibility of plots to roads in Rudna Mała after verification 
Table 7. Accessibility of plots to roads in Rudna Mała

\begin{tabular}{|c|c|c|c|c|c|c|}
\hline \multirow[t]{2}{*}{ No. } & \multirow{2}{*}{$\begin{array}{l}\text { Cadastral unit } \\
\text { name }\end{array}$} & \multirow[t]{2}{*}{ Cadastral parcels } & \multicolumn{2}{|c|}{$\begin{array}{l}\text { Number of } \\
\text { parcels }\end{array}$} & \multicolumn{2}{|c|}{ Area } \\
\hline & & & quantity & $\%$ & ha & $\%$ \\
\hline 1 & \multirow{8}{*}{ Rudna Mała } & $\begin{array}{l}\text { Parcels with access to the road recorded } \\
\text { in the Land and Building register (EGiB) }\end{array}$ & 1,530 & 40.2 & 427 & 35.0 \\
\hline 2 & & $\begin{array}{l}\text { Parcels with access to the road located in } \\
\text { a neighboring village (NV) }\end{array}$ & 30 & 0.8 & 60 & 4.9 \\
\hline 4 & & All parcels with access to roads & 1,560 & 41.0 & 487 & 39.9 \\
\hline 5 & & Parcels without access to roads & 1,776 & 46.6 & 641 & 52.5 \\
\hline 6 & & Roads & 455 & 11.9 & 62 & 5.1 \\
\hline & & Communication areas & 9 & 0.2 & 26 & 2.1 \\
\hline 7 & & Ditches and waters & 9 & 0.2 & 5 & 0.4 \\
\hline 8 & & Total: & 3,809 & 100.0 & 1,221 & 100.0 \\
\hline
\end{tabular}

As is shown in Table 7 and Figure 7, the least-favorable situation in terms of accessibility to public roads is in Rudna Mała, where as many as $46.6 \%$ of all parcels do not have access to roads. Taking into account the occupied area, this is up to $52.5 \%$ of the total area. This condition results from the occurrence of the state forests in the northeastern part of the village, which is presented in detail in Figures 7 and 8. It is also worth highlighting the situation that takes place in the areas adjacent to the motorway. On both sides of the motorway, there are clusters of small parcels without access to roads. This is similar in the case of parcels located on the western side of the railway tracks crossing the area of Rudna Mała from the southern direction to the north. A large number of parcels not served by any road are also located in the southern part of the unit. It is easy to see that this area overlaps with meadows and pastures, but that does not explain this phenomenon.

Comparing the results with the factual state, the biggest changes were made in Rudna Mała; these research results are presented in Table 8 and Figure 8. Many roads were "extended" with adjacent parcels, and many others were also included into parcels serving as passes for more-distant parcels. In all, 125 roads were added. As a result of these changes, 885 parcels gained access to the road. This is almost $23.2 \%$ of all parcels in the unit. They occupy a total of 126 ha, which constitutes $10.3 \%$ of the unit. This mainly solved the problem of access to roads in the cases of clusters of small parcels located along the motorway. The vast majority of these gained access to the road, which can be noticed in Figure 8. A significant change was also made by including a newly created provincial road. The completed investment provided a connection to the airport, but it did not guarantee access to the road for the adjacent cadastral parcels. 
Table 8. Accessibility of plots to roads in Rudna Mała after verification

\begin{tabular}{|c|c|c|c|c|c|c|}
\hline \multirow[t]{2}{*}{ No. } & \multirow{2}{*}{$\begin{array}{l}\text { Cadastral unit } \\
\text { name }\end{array}$} & \multirow[t]{2}{*}{ Cadastral parcels } & \multicolumn{2}{|c|}{$\begin{array}{l}\text { Number of } \\
\text { parcels }\end{array}$} & \multicolumn{2}{|c|}{ Area } \\
\hline & & & quantity & $\%$ & ha & $\%$ \\
\hline 1 & \multirow{10}{*}{ Rudna Mała } & $\begin{array}{l}\text { Parcels with access to the road recorded } \\
\text { in the Land and Building register (EGiB) }\end{array}$ & 1,332 & 35.0 & 410 & 33.6 \\
\hline 2 & & $\begin{array}{l}\text { Parcels with access to the road located in } \\
\text { a neighboring village (NV) }\end{array}$ & 30 & 0.8 & 60 & 4.9 \\
\hline 3 & & $\begin{array}{l}\text { Parcels with access to parcels classified } \\
\text { as roads }\end{array}$ & 885 & 23.2 & 126 & 10.3 \\
\hline 4 & & All parcels with access to roads & 2,247 & 59.0 & 596 & 48.8 \\
\hline 5 & & Parcels without access to roads & 964 & 25.3 & 517 & 42.3 \\
\hline 6 & & Roads & 455 & 11.9 & 62 & 5.1 \\
\hline 7 & & Parcels classified as roads & 125 & 3.3 & 15 & 1.2 \\
\hline & & Communication areas & 9 & 0.2 & 26 & 2.1 \\
\hline 8 & & Ditches and waters & 9 & 0.2 & 5 & 0.4 \\
\hline 9 & & Total: & 3,809 & 100.0 & 1,221 & 100.0 \\
\hline
\end{tabular}

\section{Summary and Conclusions}

After conducting a series of analyses for three villages cut off by the A4 motorway in the Głogów Małopolski commune (Lipie, Rogoźnica, and Rudna Mała), it was noted that:

1. Fragmentation of the examined area is very large. The average area of cadastral parcels in an individual sector is 0.19 ha. Some of the parcels belonging to legal persons are practically unsuitable for agricultural production due to their small areas and strip arrangement (long and narrow parcels). The impact of the parcels created by the investment connected with the motorway is clearly visible. Most parcels adjacent to it were divided into two or three new cadastral parcels, which deprived them of value in some cases.

2. The analysis of the access of parcels to roads revealed that there are significant changes in the legal and spatial situation in the examined villages. Rudna Mała has the least-developed road network. After analyzing data from the EGiB database, it turned out that only slightly more than $48 \%$ of the 
parcels have adequate access to a public road. The second village is Lipie, where more than $63 \%$ have access to any public road. Among the discussed villages, Rogoźnica has the best-developed road network. Almost $65.1 \%$ of parcels have access to the road; these occupy $77.6 \%$ of the cadastral unit area. However, this is not enough. The strip-type nature of the parcel arrangement and their dispersion make them uneconomical for land management.

3. Verification of the field data with the data from the Land and Buildings register (EGIB) showed significant disproportions and inconsistencies.

4. It turns out that some of the roads in these villages do not have their legal status regulated. Many of the parcels, which were considered inaccessible as a result of the original analysis, have had access to roads through special strips of land set out from the existing parcels.

5. The spatial structure of the analyzed area has undergone destruction as a result of the motorway construction there. The following problems have occurred:

- land fragmentation,

- areas occupied by the motorway have reduced the area for agricultural production,

- road network has been disturbed; there are problems with getting from habitats to parcels

- some of the parcels completely lost their access to the road,

- as a result of the construction work and heavy machinery used in its course, the existing elements of the network were partially destroyed,

- the level of noise has risen.

Despite the formulated recommendations, none of the analyzed villages was subjected to complex land consolidation and exchange. Action in this regard was taken only as consolidation around the motorway in Rudna Mała. On the basis of the available data, it appears that the planned land consolidation and exchange does not include the suggested area and, thus, will not be an effective process. Land exchange was completely excluded from the planned tasks; this was probably abandoned due to the difficulties connected with carrying such a task out.

The conducted research allows us to notice the unfavorable spatial situation in the analyzed area. This results not only from the area degradation caused by altered environmental conditions but also from those conditions typical for a village located in southeastern Poland. Unless corrective actions are taken in this regard, these unfavorable phenomena will increase over time. One such action is land consolidation and exchange. This would be much more efficient; however, to deal with all units or communes comprehensively (as in case of the analyzed area), the phenomena unfavorable for land use are observed not only in the area affected by the motorway. It is recommended to undertake complex tasks of land consolidation and exchange in the analyzed area. 


\section{References}

[1] Balawejder M., Adamczyk T., Cygan M.: The problem of adjusting Polish Spatial Information Resource to the standards of the INSPIRE. [in:] "GIS ODYSSEY 2016": Geographic Information Systems Conference and Exhibition: $5^{\text {th }}-9^{\text {th }}$ September 2016, Perugia, Italy: conference proceedings, Croatian Information Technology Society - GIS Forum, Zagreb 2016, pp. 14-24.

[2] Balawejder M., Buśko M., Cellmer R., Juchniewicz-Piotrowska K., Leń P., Mika M., Szczepankowska K., Wójciak E., Wójcik-Leń J., Źróbek S.: Aktualne problemy gospodarki nieruchomościami w Polsce na tle przemian organizacyjno-prawnych [Current problems of real estate management in Poland against the background of changes of organizational and legal]. Editor of monographs Balawejder M., Mika M. WSI-E, Rzeszów 2015.

[3] Balawejder M., Noga K.: The influence of the highway route on the development of patchwork of plots. Journal of Water and Land Development, No. 30, 2016, pp. 3-11, DOI: 10.1515/jwld-2016-0015.

[4] Bieda A., Stalka-Krawczyk D.: Analiza postępowań związanych z regulacja stanu prawnego dróg publicznych na przykładzie Chorzowa [Analysis of proceedings related to the regulation of the legal status of public roads on the example of Chorzów]. Zeszyty Naukowe Uniwersytetu Szczecińskiego. Studia i Prace Wydziału Nauk Ekonomicznych i Zarządzania, nr 36, t. 1, 2014, pp. 139-151.

[5] Harasimowicz S., Janus J.: Optymalny przydział gruntów do gospodarstw na tle stref różnic odległości z siedlisk do działek [An optimum land allocation to farm holdings based on zones of disparities concerning distances between homestead areas and land plots]. Acta Scientiarum Polonorum. Geodesia et Descriptio Terrarium, vol. 8, nr 2, 2009, pp. 3-12.

[6] Hopfer A., Kobyłecki A., Żebrowski W.: Kształtowanie sieci dróg na terenach wiejskich [Shaping the road network in rural areas]. PWRiL, Warszawa 1980.

[7] Matyas K.: Lesnidoprawni site - Podklady pro planowani [Planning forest road network]. Praha 1957.

[8] Noga K.: Metodyka programowania i realizacji prac scalenia $i$ wymiany gruntów w ujęciu kompleksowym [Methodology of programming and implementation of works consolidation and exchange of land in terms of complex]. Szkoła Wiedzy o Terenie, AR, Kraków 2001.

[9] Siejka M., Mika M., Salata T., Leń P.: Algorithm of land cover spatial data processing for the local flood risk mapping. Survey Review, 2017.02.22, pp. 1-7, DOI: 10.1080/00396265.2017.1287620.

[10] Sobolewska-Mikulska K.: Metodyka rozwoju obszarów wiejskich z uwzględnieniem wybranych procedur geodezyjnych w aspekcie integracji z Unia Europejska [Methodology of rural areas development with consideration of selected geodetic procedures with respect to integration with the European Union]. Prace Naukowe Geodezja, z. 44, Oficyna Wydawnicza Politechniki Warszawskiej, Warszawa 2009. 
[11] Sobolewska-Mikulska K.: Możliwości wykorzystania scaleń infrastrukturalnych w procesie przebudowy struktury przestrzennej obszarów wiejskich [Possibilities of using infrastructural consolidations in the process of reconstructing the spatial structure of rural areas]. Infrastruktura i Ekologia Terenów Wiejskich, nr 1/II, 2012, pp. 41-51.

[12] Stelmach M. [et al.]: Obszary wiejskie i grunty rolnicze w Polsce. Wyniki badań ankietowych - 1988 [Rural areas and agricultural land in Poland. Survey Results 1988]. Instytut Planowania i Urządzania Terenów Wiejskich AR, Wrocław 1990.

[13] The Act of 21 March 1985 on public roads. Official Journal 2016 No. 1440 - consolidated text, as amended [Obwieszczenie Marszałka Sejmu Rzeczypospolitej Polskiej z dnia 23 sierpnia 2016 r. w sprawie ogłoszenia jednolitego tekstu ustawy o drogach publicznych. Dz. U. 2016 poz. 1440].

[14] Wilkowski W.: Wielokryterialna metoda oceny wptywu autostrady na gospodarstwa rolne [Multi-criteria method of estimating the impact of motorways on farms]. Prace Naukowe - Politechnika Warszawska. Geodezja, z. 33, Warszawa 1995, pp. 5-19.

\section{Rozmiary destrukcji dróg dojazdowych do działek ewidencyjnych wynikające $\mathrm{z}$ wybudowania autostrady}

Streszczenie: Problematyka opracowania dotyczy oceny sieci dróg bezpośredniej obsługi działek we wsiach podzielonych autostradą. Zakres badań obejmuje analizę przestrzenną w trzech wsiach: Rogoźnica, Rudna Mała i Lipie położonych w gminie Głogów Małopolski w powiecie rzeszowskim. Na podstawie danych z części opisowej oraz kartograficznej ewidencji gruntów i budynków przeprowadzono szczegółową analizę struktury przestrzennej oraz sieci dróg bezpośredniej obsługi działek ewidencyjnych. Badania wykazały, że autostrada jako inwestycja liniowa nie tylko dokonała $\mathrm{w}$ istniejącej przestrzeni produkcyjnej destrukcji dróg rolnych, lecz jednocześnie przerwała ukształtowane od stuleci powiązania między wsiami.

Słowa

kluczowe: autostrada, sieć dróg, struktura przestrzenna, kompleksowe prace scalenia i wymiany gruntów. 